\title{
WINTER INSPECTION OF KIWIFRUIT ORCHARDS FOR SCALE
}

\author{
R.H. BLANK and M.H. OLSON
}

MAFTech, PO Box 943, Whangarei

\section{SUMMARY}

Many kiwifruit crops harvested in May 1986 in the Kerikeri district were contaminated with scale (Hemiptera: Diaspididae), despite most orchardists following the MAF export spray programme. Twelve orchards were inspected for scale during October and November 1986 after an intensive winter clean-up spray programme. Moderate to heavy infestations of live scale were found in nine orchards. Corrective action taken restricted scale contamination of the crop harvested in May 1987 to less than 12 infested fruit/1000 trays packed for all but one orchard. This study demonstrated the advantages of a pest management approach rather than reliance on a calendar spray programme.

\section{INTRODUCTION}

Scale are important quarantine pests on kiwifruit (Ferguson 1980; Sale 1980; Dale 1981). Earlier literature dealing with scale on kiwifruit has always referred to the species as greedy scale (Hemiberlesia rapax). Recent research (Lo and Blank unpublished) has shown that four closely related species of scale occur on kiwifruit. These include greedy scale, latania scale (Hemiberlesia latania), oleander scale (Aspidiotus nerii) and San Jose scale (Quadrapidiotus perniciosus). Greedy scale and latania scale are the most common species found on kiwifruit.

The presence of live or dead scale results in rejection of fruit for export. The small size of scale make them difficult to detect so that packing lines must be slowed down to enable scale infested fruit to be rejected. This adds markedly to packing costs and, even at relatively light infestations, it soon becomes uneconomic to process the crop for export.

It is essential that scale populations are kept at low levels in the kiwifruit orchard to minimise the risk of infesting fruit. Currently, growers rely heavily on a prophylactic calendar spray programme to control scale. There is little or no usage of pest monitoring to determine spray strategies as scale are considered to be difficult to detect in the orchard. There is, therefore, no check on the efficacy of control measures being applied and scale infestations can go unnoticed until they are suddenly discovered during picking and packing of the crop.

This study investigates the feasability of inspecting orchards for scale in winter or spring, before the new season's growth starts, in order to identify orchards at risk from scale contamination.

\section{METHODS}

Twelve kiwifruit orchards in the Kerikeri district were inspected for scale during October and November 1986. Orchards ranged in size from 2 to 28 canopy ha. Structures were fairly evenly divided between tee-bar and pergola, with one block of young vines on an A-frame. All but one orchard had mature vines which had been cropped for several years as well as young vines which were to be cropped for their first or second year. All orchards were sprayed using airblast sprayers except for one orchard which used a hydraulic sprayer. Spray contractors were used on four of the orchards.

Growers were advised to carry out winter clean-up spraying for scale using organophosphate insecticides, with the number of sprays dependent on infestations found on fruit at packing. Orchards were inspected for scale after the winter clean-up sprays had been applied. Inspections were carried out by four staff, experienced at

Proc. 4lst N.Z. Weed and Pest Control Conf. 
searching for scale and in distinguishing between live and dead scale. From four to six kiwifruit blocks in which the grower considered scale might be a problem, or alternatively, which were representative of the orchard were chosen for inspection. Examples of mature and young vines were included in the inspection. The time taken to detect live scale was recorded. Searchers spread out in each block and carefully examined about every tenth vine in a row. Careful attention was paid to examining the trunk and main leader. Young leaves and new season's growth were not checked. In 1987 all scale infested fruit from each orchard were collected at the grading table at packing.

\section{RESULTS AND DISCUSSION}

\section{Scale control measures and crop contamination 1985/86}

Seven growers closely followed the MAF recommended export spray programme for kiwifruit during the 1985/86 season (Table 1). This included lime sulphur and diazinon winter clean-up sprays, a pre-blossom spray of azinphos-methyl, a postblossom chlorphrifos spray, plus four or five sprays usually of phosmet and diazinon or pirimiphos-methyl/permethrin. Four growers omitted the lime sulphur and diazinon winter clean-up sprays but otherwise followed the MAF recommended spray programme. One orchard which did not produce an export crop in 1985/86 did not follow the MAF recommended spray programme. The extended flowering season, as well as the unsettled rainy weather, meant that post-blossom sprays could not be applied until about 18-22 December. This resulted in an extended interval between pre- and post-blossom sprays of approximately 46 days (range 36-56 days).

There was no obvious relationship between the $1985 / 86$ spray programme carried out and scale contamination of orchard crops detected in the packing shed (Tables 1 and 2). Heavy infestations of scale on fruit from part of one orchard caused that fruit to be rejected for export. Moderate to light infestations on fruit from another four orchards also caused problems at packing. Some scale were found on fruit from all orchards supplying the packhouse. Approximately $27 \%$ of orchards (12\% of crop) in this study had moderate to heavy scale contamination of the 1986 crop compared with $32 \%$ for all the orchards $(10 \%$ of crop) supplying the packhouse. The problem with scale contamination in this packhouse was similar to that encountered in the Kerikeri district with several large crops (10,000-15,000 trays) rejected for export. The orchards included in this study were therefore representative of the Kerikeri district.

TABLE 1: 1985/86 Spray diaries for 12 Kerikeri kiwifruit orchards.

\begin{tabular}{|c|c|c|c|c|c|c|c|}
\hline Orchar & Winter & Pre- & Post- & Jan & Feb & Mar & Apr \\
\hline 1 & ls + diaz & azin & chlo & phos & diaz & $\mathrm{p}-\mathrm{m} / \mathrm{p}$ & $\operatorname{diaz}+\mathrm{p}-\mathrm{m} / \mathrm{p}$ \\
\hline 2 & ls + diaz & azin & chlo & $\operatorname{diaz}$ & phos & phos & phos \\
\hline 3 & -- & -- & -- & -- & - & -- & -- \\
\hline 4 & ls + diaz & azin & chlo & phos & diaz & $\mathrm{p}-\mathrm{m} / \mathrm{p}$ & $\operatorname{diaz}+\mathrm{p}-\mathrm{m} / \mathrm{p}$ \\
\hline 5 & -- & azin & chlo & phos & diaz & diaz & phos \\
\hline 6 & -- & azin & chlo & $\mathrm{p}-\mathrm{m} / \mathrm{p}$ & phos & $\mathrm{p}-\mathrm{m} / \mathrm{p}$ & -- \\
\hline 7 & $1 s+\operatorname{diaz}(2)$ & ) azin & chlo & diaz & phos & $\operatorname{diaz}(2)$ & phos \\
\hline 8 & $\mathrm{ls}+\mathrm{diaz}$ & azin & chlo & $\mathrm{p}-\mathrm{m} / \mathrm{p}$ & diaz & $\operatorname{diaz}$ & $\mathrm{p}-\mathrm{m} / \mathrm{p}$ \\
\hline 9 & ls $+\operatorname{diaz}$ & azin & chlo & diaz & -- & $\mathrm{p}-\mathrm{m} / \mathrm{p}$ & $\mathrm{p}-\mathrm{m} / \mathrm{p}$ \\
\hline 10 & -- & chlo & diaz & phos & diaz & phos & diaz + phos \\
\hline 11 & ls $+\operatorname{diaz}$ & azin & chlo & phos & diaz & -- & phos(2) \\
\hline 12 & -- & azin & chlo & diaz & $\mathrm{p}-\mathrm{m} / \mathrm{p}$ & $\mathrm{p}-\mathrm{m} / \mathrm{p}$ & $\mathrm{p}-\mathrm{m} / \mathrm{p}$ \\
\hline
\end{tabular}

ls = lime sulphur, diaz = diazinon, azin = azinphosmethyl,

chlo $=$ chlorpyriphos, phos $=$ phosmet, $\mathrm{p}-\mathrm{m} / \mathrm{p}=$ pirimiphos-methyl $/$ permethrin.

TABLE 2: Kiwifruit crop production in May 1986 and 1987 and the numbers of scale infested fruit recovered from the grading table during packing for 12 Kerikeri orchards. 


\section{Winter inspection 1986}

Kiwifruit vines infested with live scale were found at all orchards (Table 3). Scale infestations were heavy on mature and young vines at one orchard and on young vines at another two orchards. At these sites scale were readily found within 1 minute of commencing inspection. Moderate infestations were found after 2 to 12 minutes inspection on mixed aged vines at seven orchards. Light infestations of scale were found after 16 minutes of inspection on mixed age vines at four orchards. No live scale were found on mature vines at Orchard 11 even after 90 minutes of searching, but some live scale were found on young non-producing vines which had not been regularly sprayed.

TABLE 2: Kiwifruit crop production in May 1986 and 1987 and the numbers of scale infested fruit recovered from the grading table during packing for 12 Kerikeri orchards.

\begin{tabular}{|c|c|c|c|c|}
\hline \multirow{3}{*}{ Orchard } & \multirow{2}{*}{\multicolumn{2}{|c|}{$\begin{array}{l}\text { Crop } \\
\text { (trays) }\end{array}$}} & \multicolumn{2}{|c|}{ Scale Contamination } \\
\hline & & & estimation & $\begin{array}{l}\text { (no. } / 1000 \\
\text { trays) }\end{array}$ \\
\hline & 1986 & 1987 & 1986 & 1987 \\
\hline 1 & 7,000 & 10,000 & unknown & 2 \\
\hline 2 & 5,000 & 10,000 & heavy & 1 \\
\hline 3 & 0 & 1,000 & unknown & unknown \\
\hline 4 & 6,000 & 8,000 & trace & 6 \\
\hline 5 & 45,000 & 89,000 & trace & 11 \\
\hline 6 & 46,000 & 77,000 & trace & 3 \\
\hline 7 & 7,000 & 12,000 & light & 46 \\
\hline 8 & 6,000 & 15,000 & moderate & 1 \\
\hline 9 & 2,000 & 8,000 & unknown & unknown \\
\hline 10 & 13,000 & 31,000 & trace & 6 \\
\hline 11 & 13,000 & 21,000 & trace & 12 \\
\hline 12 & 3,000 & 16,000 & moderate & 2 \\
\hline
\end{tabular}

TABLE 3: Levels of scale infestations, main scale location and inspection time taken to detect first live scale in kiwifruit orchards in October and November 1986.

\begin{tabular}{cllrll}
\hline Orchard & Vine age & \multicolumn{2}{c}{ Scale infestation } & $\begin{array}{r}\text { Time } \\
\text { (min) }\end{array}$ & Location \\
\hline 1 & mature & moderate & heavy & 2 & trunk \\
2 & mature & light & moderate & 30 & canopy \\
3 & young & moderate & moderate & 2 & trunk and canopy \\
4 & mature & moderate & heavy & 2 & trunk and canopy \\
4 & young & moderate & moderate & 4 & trunk and canopy \\
5 & mature & moderate & moderate & 2 & trunk \\
5 & young & moderate & moderate & 2 & trunk \\
6 & mature & light & light & 48 & trunk and canopy \\
6 & young & light & light & 19 & trunk and canopy \\
7 & mature & light & heavy & 16 & trunk \\
7 & young & heavy & moderate & 1 & trunk and canopy \\
8 & mature & light & heavy & 12 & trunk \\
8 & young & moderate & moderate & 2 & trunk \\
9 & mature & heavy & heavy & 1 & trunk \\
9 & young & heavy & heavy & 1 & trunk \\
10 & mature & moderate & heavy & 6 & trunk \\
10 & young & moderate & moderate & 5 & trunk and canopy \\
11 & mature & nil & trace & $>90$ & - \\
11 & young & light & light & - & trunk and canopy \\
12 & mature & moderate & heavy & 4 & trunk \\
12 & young & heavy & heavy & 1 & trunk \\
\hline
\end{tabular}


Scale infestations were most common on the lower trunk. Massive encrustations of up to several hundreds or even thousands of scale were found on the worst affected vines. Many of these scale had been killed by the intensive winter clean-up sprays. However, survivors were often found which were considered to pose a threat to the new season's fruit crop. Scale infestations were also found on the main leader and old wood at canopy height on mature vines at three orchards and more commonly on young vines. Typically, these infestations were small but on young vines the frequency at which these were found indicated that they also posed a threat to contamination of fruit.

The most common reason for scale infestation appear to be failure to provide full spray coverage of vines, the use of herbicide spray guards around the trunks, and failure to spray young non-cropping vines.

\section{Scale control measures and crop contamination 1986/87}

An intensive winter 'clean-up' spray programme was recommended in 1986 to all growers, following the poor scale control achieved on the 1985/86 crop. During orchard inspections further corrective measures were strongly recommended for many orchards. Depending on individual circumstance, this may have involved additional insecticide sprays or special applications directed at infested trunks. In addition, at some orchards, removal of spray guards and/or improvement in weed control was to be carried out in conjunction with the spraying. No winter clean up sprays were applied to Orchard 6 (Table 4). All other orchards received one or two more winter clean-up sprays than that recommended in the MAF export spray programme.

TABLE 4: $\quad$ 1986/87 Spray diaries for 12 Kerikeri orchards

\begin{tabular}{|c|c|c|c|c|c|c|c|c|}
\hline $\begin{array}{l}\text { Orch- } \\
\text { ard }\end{array}$ & Winter & $\begin{array}{l}\text { Pre- } \\
\text { blossom }\end{array}$ & $\begin{array}{l}\text { Post- } \\
\text { blossom }\end{array}$ & Jan & Feb & Mar & Apr & May \\
\hline 1 & ls $+\operatorname{diaz}(2)+$ chlo & azin & phos & $\begin{array}{l}\text { diaz } \\
+ \text { phos }\end{array}$ & $\begin{array}{l}\text { diaz } \\
+ \text { phos }\end{array}$ & diaz & $\begin{array}{l}\text { phos } \\
+\mathrm{p}-\mathrm{m} / \mathrm{p}\end{array}$ & - \\
\hline 2 & ls $+\operatorname{diaz}+\operatorname{chlo}(2)$ & $\mathrm{p}-\mathrm{m} / \mathrm{p}$ & phos & $\operatorname{diaz}(2)$ & $\mathrm{p}-\mathrm{m} / \mathrm{p}$ & $\begin{array}{l}\mathrm{p}-\mathrm{m} / \mathrm{p} \\
+\operatorname{diaz}\end{array}$ & $\mathrm{p}-\mathrm{m} / \mathrm{p}$ & - \\
\hline 3 & ls $+\operatorname{diaz}+\operatorname{chlo}(2)$ & $\mathrm{p}-\mathrm{m} / \mathrm{p}$ & phos & $\operatorname{diaz}(2)$ & $\mathrm{p}-\mathrm{m} / \mathrm{p}$ & $\begin{array}{l}\mathrm{p}-\mathrm{m} / \mathrm{p} \\
+\mathrm{diaz}\end{array}$ & $\mathrm{p}-\mathrm{m} / \mathrm{p}$ & - \\
\hline 4 & ls $+\operatorname{diaz}(2)+$ chlo & chlo & phos & diaz & $\operatorname{diaz}$ & $\operatorname{diaz}$ & $\mathrm{p}-\mathrm{m} / \mathrm{p}$ & - \\
\hline 5 & ls + diaz + chlo & chlo & phos & diaz & $\begin{array}{l}\text { phos } \\
+ \text { diaz }\end{array}$ & phos & $\mathrm{p}-\mathrm{m} / \mathrm{p}$ & - \\
\hline 6 & - & azin & phos & $\mathrm{p}-\mathrm{m} / \mathrm{p}$ & $\begin{array}{l}\mathrm{p}-\mathrm{m} / \mathrm{p} \\
+\mathrm{phos}\end{array}$ & $\operatorname{diaz}$ & - & - \\
\hline 7 & $\operatorname{diaz}+\operatorname{chlo}(2)$ & chlo & phos & diaz & phos & phos & $\begin{array}{l}\text { phos } \\
+ \text { diaz }\end{array}$ & - \\
\hline 8 & ls + diaz + chlo & azin & phos & $\begin{array}{l}\text { diaz } \\
+\mathrm{p}- \\
-\mathrm{m} / \mathrm{n}\end{array}$ & diaz & $\mathrm{p}-\mathrm{m} / \mathrm{p}$ & $\mathrm{p}-\mathrm{m} / \mathrm{p}(2)$ & - \\
\hline 9 & ls $+\operatorname{diaz}+\operatorname{chlo}(2)$ & $\mathrm{p}-\mathrm{m} / \mathrm{p}$ & $\mathrm{p}-\mathrm{m} / \mathrm{p}$ & $\begin{array}{l}\text { phos }+ \\
\text { p-m/p }\end{array}$ & $\operatorname{diaz}$ & $\mathrm{p}-\mathrm{m} / \mathrm{p}$ & $\mathrm{p}-\mathrm{m} / \mathrm{p}$ & $\mathrm{p}-\mathrm{m} / \mathrm{p}$ \\
\hline 10 & $\operatorname{diaz}(3)+$ chlo & chlo & $\begin{array}{l}\text { phos } \\
+ \text { diaz }\end{array}$ & phos & phos & diaz & - & - \\
\hline 11 & $\operatorname{diaz}+$ chlo & chlo & phos & $\mathrm{p}-\mathrm{m} / \mathrm{p}$ & phos & diaz & phos & - \\
\hline 12 & ls $+\operatorname{chlo}(2)$ & chlo & phos & diaz & $\begin{array}{l}\text { diaz } \\
+ \text { phos }\end{array}$ & $\mathrm{p}-\mathrm{m} / \mathrm{p}$ & $\begin{array}{l}\mathrm{p}-\mathrm{m} / \mathrm{p} \\
+\operatorname{diaz}\end{array}$ & - \\
\hline
\end{tabular}

abbreviations as for Table 1.

In January and February 1987 high levels of scale invasion were detected on unsprayed kiwifruit trap plants placed in orchards (Blank et al 1987, Blank unpublished). Additional sprays were then recommended and an average of 5.3 sprays were applied to the twelve orchards after the post-blossom spray (Table 4). Growers were successful in keeping scale contamination on the 1987 crop to very low levels with 11 orchards having less than 12 scale infested fruit/1000 trays (Table 2). Moreover, in 
Orchards 5 and 6 much of the scale detected came from a small localised area with the rest of the orchards relatively free of scale. Only one orchard had a significant problem with scale in 1987, most of which originated from young first year producing vines which had not received additional sprays as recommeded. Overall a very successful result was achieved with scale being relegated to a pest of relatively minor importance at packing in contrast to the major problems encountered the previous season.

It was of concern that scale infestations occurred in orchards where the MAF export spray programme for kiwifruit had been closely followed in 1985/86, as in previous seasons. This does not necessarily imply that the spray programme was at fault but, rather, it illustrates how a blind reliance on a calender spray programme can give rise to a false confidence that pests are being controlled. Furthermore, the calendar spray programme currently fails to recognise the variable risk of scale and other pest infestations in different orchards. This study has demonstrated that experienced personel can detect scale infestations in kiwifruit orchards, shifting the emphasis towards pest management rather than sole reliance on a calendar spray programme, with considerable benefits for the growers.

\section{ACKNOWLEDGEMENTS}

We wish to thank Keripackers Co-operative Ltd and the many kiwifruit growers for their support with this project. Our thanks to Mrs J. Kelly, Miss M.L. Bailie and the late Mr D.S. Bell for assistance with orchard inspections.

\section{REFERENCES}

Blank, R.H., Olson, M.H. and Bell, D.S., 1987. Invasion of greedy scale crawlers (Hermiberlesia rapax) onto kiwifruit from taraire trees. New Zealand Entomologist 10: 127-130.

Dale, P.S., 1981. Greedy Scale Biology, Damage and Control on Kiwifruit. Aglink HPP32, MAF, Wellington, New Zealand.

Ferguson, A.M., 1980. Major causes of imperfections in the Bay of Plenty kiwifruit crop. Proc. 33 rd NZ Weed and Pest Control Conf.: 92-95.

Sale, P.R., 1980. The history of pest and disease control in kiwifruit. Proc. 33rd NZ Weed and Pest Control Conf.: 110-113 